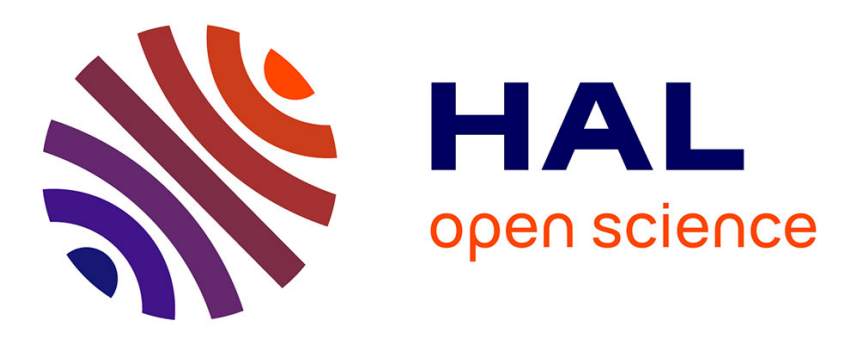

\title{
The Visibility of Survival: Even the Dogs and Jon McGregor's Ethics of Attention
}

\author{
Jean-Michel Ganteau
}

\section{To cite this version:}

Jean-Michel Ganteau. The Visibility of Survival: Even the Dogs and Jon McGregor's Ethics of Attention. Rudolf Freiburg; Gerd Bayer. The Ethics of Survival in Contemporary Literature and Culture, Springer International Publishing, pp.49-67, 2021, 978-3-030-83421-0. 10.1007/978-3-03083422-7_2 . hal-03565038

HAL Id: hal-03565038

https://hal-univ-montpellier3-paul-valery.archives-ouvertes.fr/ hal-03565038

Submitted on 10 Feb 2022

HAL is a multi-disciplinary open access archive for the deposit and dissemination of scientific research documents, whether they are published or not. The documents may come from teaching and research institutions in France or abroad, or from public or private research centers.
L'archive ouverte pluridisciplinaire HAL, est destinée au dépôt et à la diffusion de documents scientifiques de niveau recherche, publiés ou non, émanant des établissements d'enseignement et de recherche français ou étrangers, des laboratoires publics ou privés. 


\title{
The Visibility of Survival: Even the Dogs and Jon McGregor's Ethics of Attention
}

\author{
Jean-Michel Ganteau
}

In many ways, the definition of survival is intricately enmeshed with the memory of the Shoah. Over the last seventy years, it has repeatedly been considered in the light of the extreme experience of the death camp, at least since the publication of Primo Levi's If This Is a Man (1947, translated into English in 1959). The raft of testimonies relating the experience of the Lager, like those written by Jean Améry in Austria or Robert Antelme in France, contributed to an increased attention to survival and stabilised the association with the death camp. From narrative accounts written by survivors the notion then spread towards philosophy and, more generally, theory, with very influential texts like Giorgio Agamben's Remnants of Auschwitz (1999, translated 2002) that directly addresses the issue of surviving the camp experience, George Didi-Huberman's Images in Spite of All (2003, translated 2008), or else Jean-François Lyotard's The Differend (1983, translated 1988), some of those texts sparking off virulent controversies, as was the case with Didi-Huberman's. Such works are characterised, above all, by the centrality granted to the figure of the witness and, correlatively, to the form of testimony. Following in Levi's wake, Agamben argues that the real witness is no longer alive, having gone through the extermination process, hence that the survivor is to be distinguished from the true witness. ${ }^{1}$ He pinpoints a central paradox in the terms of which even if testimony is the condition of survival, ${ }^{2}$ such an account is by definition flawed or incomplete in that its value resides precisely "in what it lacks": to him, testimony allows for "bearing witness to a missing testimony". ${ }^{3}$ The idea of the lack or failure, powerfully expressed through the figure of the lacuna, is also prevalent in Lyotard's work on the differend: "I would like to call a differend [differrend] the case where the plaintiff is divested of the means to argue and becomes for that reason a victim. If the addressor, 
addressee, and the sense of the testimony are neutralized, everything takes place as if there were no damages." context, a form characterised by incompleteness, incapacity, limitation and other types of losses that turn it into a paragon of vulnerable form.

This is perhaps the reason why the idea of survival and the narrative forms attached to it were granted such prominence in trauma theory and criticism, an emblematic aspect of the memory turn that came to dominate academic and other concerns over the past few decades. One of the founding references as regards the double issue of survival and testimony is certainly Shoshana Felman and Dori Laub's Testimony: Crises of Witnessing in Literature, Psychoanalysis and History (1992), where Felman describes the form in terms of a "crisis of truth" while addressing the shift from the legal to the cultural field of application of the notion: "What, however, are the stakes of the larger, more profound, less definable crisis of truth which, in proceeding from contemporary trauma, has brought the discourse of the testimony to the fore of the contemporary cultural narrative $[\ldots] ?^{, 5}$-- she asks, at the beginning of the first chapter. And such a crisis Laub attributes to the Shoah as "An Event without a Witness":

what precisely made a Holocaust out of the event is the unique way in which, during its historical occurrence, the event produced no witnesses. Not only, in effect, did the Nazis try to eliminate the physical witnesses of their crime; but the inherently incomprehensible and deceptive psychological structure of the event precluded its own witnessing, even by its very victims. ${ }^{6}$

Survival, then, is evidently germane to the main tenets of trauma theory, based as it is on the founding unassimilability of a violent event, either provoked through a single breakthrough or by enduring exposure to abuse. From this point of view, it is certainly not fortuitous that the notion should be given such eminence in Cathy Caruth's ground-breaking and influential Unclaimed Experience in which she records the "peculiar and perplexing experience of survival"7 and formulates what to her mind is a crucial issue: "The problem of 
survival, in trauma, thus emerges specifically as the question: what does it mean for consciousness to survive?" More precisely, she insists that the lateness inherent in the elaboration of trauma and the victim's realisation that $\mathrm{s} / \mathrm{he}$ is still alive after an extreme encounter with violence jeopardises any understanding of survival: "the trauma consists not only in having confronted death but in having survived, precisely, without knowing it. What one returns to in the flashback [as a modality of traumatic repetition] is not the incomprehensibility of one's near death, but the incomprehensibility of one's survival". 9 Trauma studies were therefore extremely influential in broadcasting the issue of survival in general and of survivor's trauma in particular.

Thanks to the collaboration between psychoanalysis and literature, one of the figures towards which the issue of survival has migrated is that of the spectre. The compulsion to repeat and the traumatic re-enactment of unassimilated episodes was naturally envisaged through the prism of revenance, at times linked with the Shoah. This is evidenced, for instance, in Gabrielle Schwab's Haunting Legacies: Violent Legacies and Transgenerational Trauma (2010). It should be added that a notion akin to survival, survivance, has also been fairly influential over the last few decades, perhaps thanks to Didi-Huberman's work on Aby Warburg, The Surviving Image: Phantoms of Time and Times of Phantoms: Aby Warburg's History of Art (2002). In this study, Didi-Huberman considers Warburg's model of history as spectral, characterised by haunting and survivance replacing the chronological model of academic transmission. ${ }^{10}$ Such an idea is encapsulated in the term Nachleben-or afterliving - referring to a being of the past that goes on existing or, more precisely, surviving. ${ }^{11}$ From the violent denotations of "survival" to the more resilient connotations of "survivance" — defined by Didi-Huberman as some humble, muted permanence which, though latent, remains indestructible - the notion seems to have evolved over the last two decades, or at least to have developed in two directions at the same time, while retaining a common core of 
meaning. In any case, it does loom large over the fields of theory and literary studies, carrying in its wake a string of associations like violence, extremity, trauma, temporal disjointing, spectrality, testimony, lacuna, incomprehensibility and impossibility, a whole array of negative, privative connotations that clearly emanate from the historical context in which its theorisation emerged before being applied to sundry other fields. Survival has become ubiquitous.

Fiction-and perhaps more especially experimental fiction-has taken the responsibility to address the issue of surviving. To take one obvious, though contentious example, this is the case with Martin Amis's Time's Arrow, or, The Nature of the Offence (1991), which mobilises the powers of fiction to transcend the limits of non-fictional testimony and precisely go beyond the ontological and epistemological limitation of the lacuna put forward by Agamben and relentlessly delve into the eponymous nature of the offence. This it does by concentrating on the controversial theme of perpetrator trauma and survival, as its protagonist is a doctor working in Birkenau during WWII, whose task it was to contribute to various types of experimentations on human beings and to take part in the extermination of the inmates. The notorious fact that the narrative is written in reverse, starting with the return to life of the old doctor and ending up with his regressus ad uterum, and the fact that it is recounted through the means of an estranged, split narrative voice possibly attributed to the eloquence of the narrator's spectral soul, answers the need to expose the whole truth - or at least an impression of it - , hence to go beyond the limits of nonfictional testimony, thereby fuelling fiction's ethical capacity to state it all.

Still, for this essay I have chosen to concentrate on another, more recent novel, which does not take its inspiration from the Shoah context and makes the reader plunge into the margins of contemporary cities, among an invisible, submerged population of vagrants, drugaddicts and tramps - without, of course, in any way wanting to efface the singularity and 
incomparable character of an event like the Shoah. Jon McGregor's Even the Dogs (2010) opens with the discovery of a corpse, that of Robert, an unemployed ex-soldier turned alcoholic, who died over the Christmas break as he was left on his own, with all the fellow addicts and dossers that used to stay with him and to bring him food and drink in exchange for shelter having evaporated on various errands over the festive season. The novel also resorts to the powers of experimentation with an innovative choral narration, as the narrator uses the first-person plural and speaks from somewhere else, as if from beyond the grave. Such a narrative choice seems to be efficient in bypassing the limitations traditionally associated with testimony. In fact, the spectral chorus seem to have gone through the experience of extreme suffering and death. Even if these choral voices were absent when the central character, Robert, died, by surviving him as narrators they activate the ethical pole of fictional testimony and bear witness to similar experiences of exposure and deprivation. The spectral survivors, both present and not all there, both invisible and incarnated, renew the figure of the survivor as they reach beyond the limitations of the lacuna, doing away with unsayability and impossibility so as to plunge, once more, into the nature of the offence and to make testimony come to fruition. My point is that Even the Dogs throws the mechanics of survival into an unblinking light through its experimental vein. It casts a new spell on what surviving may mean, and on the possibilities of witnessing, against the grain of contemporary definitions.

This is what I shall attempt to demonstrate in the first part of this essay by exploring surviving in its transitive meaning, as one survives someone, which will lead me to attend to the elegiac dimension of the novel. The second part will be devoted to the figure of the witness as superstes and to survival as experience. I shall conclude on the text as an ethical means to train attention to survivors, reclaiming them from invisibility.

\section{Survival and the figure of elegy}


As suggested above, I find it relevant to recall that "to survive" is also a transitive verb, as one always survives someone or something. Hence survival is generally conceived of in terms of loss, as it implies attachment to those who did not make it. I would thus argue that, along with the form of testimony that has consistently been associated with it, survival is indissolubly connected to the elegiac. What I mean here is not so much funeral elegy as a genre (generally associated with poetry) as with elegy conceived of as a "mood" that bleeds into and informs various types of texts, ${ }^{12}$ among which are also found novels. On that account, it may be said that Even the Dogs owes much to this mode. In fact, it hinges on the death of a central character and each of its five chapters is devoted to an action performed around the corpse, from its initial discovery to its final cremation, through the long autopsy executed in Chapter Four. The collective narrator may be considered as a chorus representing the voices of the citizens-in the tradition of classical tragedy coryphaeus-, reversing the reader's expectations and insinuating that the representatives of the submerged, marginalised population have come to assume the part of the original ordinary citizens, cast in the role of self-proclaimed, invisible and hardly audible mourners. ${ }^{13}$ The choral narrators are, indeed, invisible, as they rub shoulders with the other characters (the policemen who discover the corpse in Chapter One, the ambulance drivers in Chapter Two, etc.), observing them while remaining unnoticed or unseen by them; and inaudible as they speak to themselves and, implicitly, the reader, without ever being heard by the rest of the cast. This clearly testifies to their spectral status and puts centre stage the theme of invisibility. Above all, this allows them to discreetly observe all marks of attention lavished on Robert's corpse, a care that he distinctly missed when he was alive. ${ }^{14}$ The spectral status thereby allows for the omnipresence of witnesses and an even more acute ability to observe and testify.

In many ways, the reader is confronted with the choral narrator's relentless wish to tell everything and to testify fully, bearing witness to what is happening to Robert's remains in 
the present and to his former life, allowing the past to invade and repeat itself in the present as in the first chapter, where anachronism allows for constant shifts between the happy, healthy past of the couple who used to inhabit the newly redecorated flat (Robert and his former partner, Yvonne) and the present dominated by loneliness and dereliction, time accelerating in cinematic fashion:

The steam from the bath curls out into the hallway, easing the wallpaper away from the wall. Peppered spores of mould thicken and spread towards the ceiling. Rainwater seeps through the worn pointing on the front of the building and pushes through the plaster, the damp spreading outwards like an old bruise. ${ }^{15}$

Knowledge of the past, of the sort that makes its vivid repetition possible, allows for the creation of an almost fully-fledged testimony. Of course, the witnesses were not around when Robert died, but the autopsy and inquest will provide a post-mortem reconstitution, and access to the past offers both an overall and precise view of Robert's own excruciating experience of survival (of the war, of the breaking down of his couple, of his forfeiting all hope of recovery). Surviving the former survivor seems to be their main task and takes the form of a permanent, endless monologue. It seems as if a complementary yet essential function of the chorus of survivors were not only to tell so as to prolong the life or at least cultivate the memory of the departed but also to keep telling so as to go on bearing witness, i.e. recounting so as to survive. Such a reality is integral to the survival process, according to Laub among others, even if Laub concentrates on an altogether different historical context. In his terms, "testimony is $[\ldots]$ the process by which the narrator (the survivor) reclaims his position as a witness". ${ }^{16}$ Taking one step further, Laub reminds us that "testimony is inherently a process of facing loss". ${ }^{17}$ Still, I would argue that where traditional elegy has a performative functioni.e. that of helping the poet/narrator/survivor go to the end of the work of mourning, thereby coming to terms with loss and accepting a return to normal life beyond pathological attachment to the departed, in conformity with the dynamics of mourning as notoriously 
analysed by Freud ${ }^{18}$ - Even the Dogs presents the reader with an interminable vigil or wake that fails to come to an end and seems to achieve some immanent status.

In fact, the departed protagonist, Robert, used to spend his days waiting for his friends to bring him food and cider, and for his former partner and daughter to come back, as made clear in the first chapter and regularly recalled in the rest of the book. And what the spectral chorus do-reduced as they are to their narrative, testimonial function-is just that: wait for the police to do their jobs in Chapter One, wait for the ambulance to cross the city in Chapter Two, keep a vigil on Robert's corpse in the mortuary in Chapter Three, attend the whole autopsy in Chapter Four and stay around while the coroner interviews the other, living witnesses and gives his conclusions as to what brought about Robert's death throughout Chapter Five. Tellingly, the novel winds up on an official injunction to rise, followed by the chorus's final words: "We rise. What else can we do, we fucking rise". ${ }^{19}$ Reduced to a painstaking passivity, assigned the task of indefinitely waiting, the spectral survivors cum witnesses turn the novel into a never-ending wake. For in fact it seems as if their vigil were eternal, taking place in an endless present that is not so much that of hell (the epigraph to the novel is borrowed from Dante's Inferno) but from some latter-day evocation of limbo, very much in the line of Coleridge's famous poetic version of this heterotopia:

Tis a strange place, this Limbo! — not a Place,

Yet name it so; —where Time and weary Space

Fettered from flight, with night-mare sense of fleeing,

Strive for their last crepuscular half-being; - $^{20}$

Caught in the suspended, eternal present of limbo-possibly a figure of the traumatic presence of the past-, the narrators/survivors stretch time and the unending vigil, all their 
agency concentrated on the dedicated, incandescent expression of a sense of loss. In so doing, they become figures of exposure to dependence on the departed whose main function is to express some belated solidarity and post-mortem interdependence with the deceased.

What distinguishes the novel from the more traditional forms of elegy, though, is that -its temporality being that of an endless, traumatic present -- mourning has been replaced by melancholia or melancholic mourning, as expressed in the freezing of chronology, hence the impossibility of consolation. Such a trait has been identified as a characteristic of contemporary elegy by Jahan Ramazani, who underlines "the absurdity of elegiac expectation" and casts doubts on the consolatory powers of the modern form. ${ }^{21}$ Now, melancholia assumes an essential ethical function in the narrative by acting as the warrant for a continuing testimony to the departed-hence as a condition for an on-going engagement with witnessing. Thanks to survivors' melancholia, the traditional idea at the heart of the literature of testimony and survival expressed in Michael G. Levine's idea that survival is caught in intrinsic limitations is gainsaid. Against Levine's vision of the "effort to listen to stories carried by the survivor that exceed his or her capacity to access and relate", ${ }^{22}$ Even the Dogs proposes a conception of the belated, spectral witness as a contemporary witness whose perceptual and attentional powers fuel his/her gift of the gab. The novel thereby flaunts the relentless survivor's responsibility to tell everything. The elegiac form lends itself to the expression of a "fantasy of care" for the departed that seems to be devoid of the revisionary wish at the heart of elegy. ${ }^{23}$ Instead of revision, it prefers melancholic faithfulness to the lost - an ethics of melancholy that warrants a literary and ethical experience of surviving through witnessing. From this point of view, the experience of survival appears as determined by exposure to the lost other and positions the survivor/narrator as the repository of adamant relationality, hence vulnerability to the other. 


\section{Experiencing survival}

The cast of characters in Even the Dogs gathers together a sample of typical cases: people who lost their jobs and families (Robert), children who were abandoned and raised by surrogate parents (Danny) or former soldiers. This is the case with Robert, who fought for his country, and with Steve, who went to the Falklands, Northern Ireland and found himself in other war zones like Bosnia. In Chapter Three, the chorus allow him to speak and evoke a situation when Steve, trying to go through rehab, reluctantly attended a speaking group led by a "facilitator" and never managed to testify:

Is there something you'd like to share with the rest of the group. Well, no there isn't as a matter of fact. If I told you half this stuff you'd have nightmares for a month, or you'd think I was lying and kick me out. Was about all he ever said in that group. My country lied to me and I'd rather not go into it all. I'd rather not share all that with the group, if you don't mind, he said. ${ }^{24}$

Here, the traditional arguments explaining the impossibility of testimonies are summoned: the extremity of the experience, the concomitant fear of contamination and the dread of disbelief or denial that condemn the survivor to dumbness. Still, I would argue that such passages are emblematic of what precisely the novel stands against, in its will to muster the powers of experimental fiction - through its innovative use of spectral, first-person plural narrative form, its idiosyncratic presentation of character discourse and its densely poetic form - so as to whittle away the limitations imposed on witnessing.

As suggested above, the narrative apparatus obeys the rules of maximum sayability and experience by disconnecting physical presence from voice through spectral narration, thereby giving access to all aspects of the deceased man's life and to that of the rest of the cast of characters. The spectral chorus, both invisible and incarnated, are omnipresent through their common voice and the permanence of a "we" that awkwardly echoes throughout. Even if they never directly address the reader, the resounding omnipresence of the first-person plural 
creates a defamiliarising effect that draws attention to the origins of the voice and to its enunciative parameters. More precisely, the impression, throughout, is that the "we" solicits the reader's consideration and that, even though indirectly inscribed - there is no explicit presence of a "you"-, a distinct sense of address dominates the narrative. Now, address is at the heart of the witnessing process, and it is in many ways what constitutes the survivor, who survives, precisely, by addressing someone. This is what Laub reminds us of when describing the witness as a survivor who "reconstitutes the internal "thou" so as to stay alive and project him-/herself beyond the unbearable present. ${ }^{25}$ Levine has also emphasised the survivor's need to "look[...] for a you" as there cannot be a witness, ${ }^{26}$ hence a survivor, without an addressee, and as each witness needs a witness to perform his/her testimony. And this is perhaps what Judith Butler has in mind in Giving an Account of Oneself when she states that "the 'you' comes before the we, before the plural you and before the they". ${ }^{27}$ In other terms, each witness and survivor is intrinsically relational and exposed to the other and, one step further, in radical need of the other, albeit an internal other, as indicated by Laub. Such a situation has led Peter Arnds to evoke the situation of the survivor as witness in terms of translation of the experience of surviving. He reminds us that "[t]ranslation implies survival. The surviving witness tries to bring to the other side a reality that eludes the witness himself, but even more so those who have not experienced it". ${ }^{28}$ Once again, translation implies the presence of an addressee, which makes the survivor the emblem of dependence on the other; and the reader, the figure of reliance on the survivor. Through its ostentatious, at times unpalatable use of the first-person plural, the novel stages the demise of autonomy as the prerogative of the sovereign subject that was supposed to characterise modernity. ${ }^{29}$ Conversely, it provides an experience of interdependence and relationality, giving pride of place to dispossession and exposure as central to the process of surviving, which is encapsulated in Alasdair McIntyre's insistence on our dependence on others for survival. ${ }^{30}$ 


\section{Attention to invisibilities}

That the incessant resort to address should be at the heart of the practice of witnessing and survival is also a way of reminding us that the etymology of "witness" is varied and that it also originally refers to the superstes or the one who has lived through the stated experience. ${ }^{31}$ Such a notion goes against the grain of contemporary visions of testimony as compounded of silence and impossibility. The superstes is more specifically associated with the capacity of total exposure to the event, and I would argue that this is what Even the Dogs, by resorting to a beautiful, densely poetic prose, ${ }^{32}$ precisely purports to do. This is made possible by the spectral device allowing for a considerable enlargement of perception that still falls short of omniscience the better to provide the conditions for a more complete recording and witnessing. The fact that the spectral chorus should be patiently waiting in the mortuary, before and throughout the autopsy, clearly provides the conditions for total vision, as indicated in this unblinkingly sensational episode:

They come through and they stand around his body, still safely bagged and sealed, and they talk, telling each other what they know about the case, reading the policeman's report, studying the notes.

They shift him on to a large steel table with a sink built in to one end, and taps, and hoses, and extraction fans which begin to whistle softly as they talk.

They weigh him and measure him and take pictures of his shrouded body. They switch on the overhead lights, searchlight-bright and stark and shocking. ${ }^{33}$

Under the glaring light of the operating theatre the various parts of Robert's corpse are cut into pieces, sampled and processed, and the doctors reveal deep layers of the dead man's body, thereby literally plunging into his vibrant intimacy:

We move in close around his body again, our hands resting on the table, and peer in at the strange swollen gleam of his insides, the flabby organs crammed wetly in upon each other. The doctor scrapes away more layers of creamy yellow fat, slices through a series of arteries and veins, and then lifts the organs out as a single block, easing them on to a plastic tray $[\ldots]^{34}$ 
Throughout the autopsy, the possibility of total access is performed by the narrative, the spectral survivors being obscenely granted access to the whole of the experience, which transforms them into emblems of the witness as superstes. While cringing at the spectacle, eyes wide open, they indulge in belated fantasies of care, voicing what they would have liked to do to offer Robert a decent burial, thereby expressing an indomitable sense of survivor's guilt while simultaneously channelling the reader's.

Such passages seem to me to testify to fiction's capacity to bear witness to the most extreme situations and to produce effects on the reader's reality. This is explained by French philosopher Myriam Revault d'Allonnes, who, while working on what she considers the alleged crisis of representation from Ancient times to the present, underlines fiction's "ability to have a reality effect and an effect on reality", which leads her to conclude that "representation $[\ldots]$ is neither a reflection nor a transfer: it makes what did not exist before happen". ${ }^{35}$ And in fact, what Even the Dogs brings into existence, by providing an experiential reading based on narrative experimentation, is a confrontation with and exposure to something that approximates to the violent totality of the event and to the experience of surviving in front of such knowledge. More specifically perhaps, experimental fiction of the type favoured by McGregor reminds us that the attention to experience solicited by literature, by getting us to attend to singularities instead of generalities, contributes to a definition of the ethical, as underlined by Sandra Laugier, following in Martha Nussbaum's wake. ${ }^{36}$

The fictional presentation of survivors provides some form of incarnation, all the more so when the process of address and solicitation is given pride of place, and when appealing to the reader's sensations and affective response is as strongly determined as in a novel like McGregor's. This is a powerful reminder that, in Corine Pelluchon's terms, ethical reflection always "finds its roots in the body", 37 and that ethics "is not based on science or on philosophy; it primarily relies on the subject's experience of the world and of him-/herself, on 
his/her intellectual representations, on his/her values and emotions". ${ }^{38}$ The novel provides as full as possible an experience of what surviving implies, eschewing silences and blurred images, unblinkingly staring in the face of the event. This it does by practising singularisation and incarnation, "situating representation at the point when zoē and bios meet, this point where bare life is always already a biopolitics [...] and where, reciprocally, biopolitics is overtaken by a bare life". ${ }^{39}$ In Even the Dogs, the account of survival is also the incarnated presentation of experience as an ethical gesture.

That the ethical and political dimensions of fictional testimony are at the heart of McGregor's project brooks little ambiguity. As underlined by the critics who have so far engaged with the novel, Even the Dogs is very much concerned with politics and intervenes in the collective debate by performing a politics of literature. This is suggested by Barbara Korte and Georg Zipp, who stress the affinity between John Berger's King, A Street Story (1999) and McGregor's third novel, ${ }^{40}$ and I have also studied the text as an example of the contemporary state-of-Britain novel. ${ }^{41}$ Obviously, one of the novel's main points is to tackle the issue of social invisibility and to do so by throwing centre stage the lives of submerged populations who seem to be excluded from society and yet keep living — surviving — in its wings, being both outside and inside, or more precisely living in "an outside that is inside", as analysed by French philosopher Guillaume Le Blanc. ${ }^{42}$ Such an invisibility he also describes in terms of latency, when he speaks of the existence of the excluded as "lives waiting for confirmation but that must remain underground, hidden". ${ }^{43}$ Now, it seems to me that such words apply neatly to Even the Dogs, with its supernumerary army of spectres whose lives go on thanks to their "survival skills", ${ }^{44}$ who remain hidden from the view of ordinary citizens, most of the latter turning a blind eye on them. Still, neither Le Blanc nor McGregor are happy with this situation; and both are very much willing to harness the powers of vulnerable, 
submerged populations to help shift the perceptual goal posts. This is what Le Blanc has in mind when he avers that "invisibility is not subtracted from politics: it reformulates it [, as] the conception of politics cannot be reduced to activities declared as political and must extend to infra-political activities". ${ }^{45}$ I would argue that, among the activities that are not officially declared as political, surviving is given pride of place in a novel that retrieves the survivors from invisibility.

By making the choral narrator omnipresent, by granting them the function of the precarious yet full witness, by giving them access to Robert's family past, to Ant's military action in the poppy fields on Afghanistan where he lost his leg, by allowing them to track Danny on his final course towards the next and last injection (as he is dying in a telephone box), by letting them and the reader be privy to Laura's failed attempt to get "clean", the narrative makes us rub shoulders with both the invisible characters and the spectres, figures that we would be tempted to ignore when passing them in the streets. In this way, we are reminded that vulnerability_-bodily, but also psychological, economic and social—is a common condition or possibility: “But all Robert's bruises don't count for much. Everyone's got them, after all. All of us. Bruises and the rest of it: cuts and grazes and sprains and breaks, abscesses and open infected sores". ${ }^{46}$ We are also reminded that vulnerability, in its extreme version as survival, is kept hidden in contemporary cities and metropolises for the comfort of ordinary citizens. By concentrating on such figures of vulnerability and of power mobilised towards surviving, the novel promotes a definition of ethics as "attention that it lavishes on the figures of vulnerability" and, I would add, of survival. ${ }^{47}$ In so doing, it makes the reader realise that what is at stake in any ethical engagement is perception, as attention to the otherthe submerged, relegated and excluded other, here. One step further, it specifies that invisibility is not a given but a social construct. ${ }^{48}$ Similarly, the novel teaches us that "perception is no natural quality and that it is much more a social activity that makes relevant 
elements, worthy to be perceived, emerge in the subject's environment". ${ }^{49}$ By considering what generally escapes perception, McGregor trains the reader to be attentive to a "negative phenomenology"50 that he translates into a poetics of obscenity, in so far as the novel shows what is generally kept in the wings or underground. In other words, Even the Dogs promotes attention to survival practices and to the proximity of survival as practice, and it even trains the reader's attention to such realities.

McGregor's ethical work consists in soliciting the reader's "right to look" against what Nicholas Mirzoeff has defined as visuality, i.e. "both a medium for the transmission and dissemination of authority, and the means for the mediation of those subjects to that authority". ${ }^{51}$ More specifically, the novel opposes the official visuality of video cameras and CCTV systems ${ }^{52}$ to "countervisuality" devices ${ }^{53}$ that are associated with the spectral survivors' patient and acute gaze, granting the other members of the cast "the right to be seen", 54 even while securing it for themselves. As an apparatus designed to favour the possibilities of countervisuality, the novel aims at both ethical and political efficiency. It reminds us that ethics is based on "perceptive exploration",55 and that attention to the humble and the submerged is always already entrammelled in social relationships. One of the novel's priorities is to make surviving visible and, one step further, to train the reader's consideration to the reality of survival. In so doing, it contributes to empower the submerged by displacing received ideas and images and by helping "invisibility to reformulate the political". ${ }^{56}$ Seen from such a perspective, this melancholy elegy should not be considered as a conservative, nostalgic piece but, quite on the contrary, as the expression of an ethical faithfulness to the departed, to the witnesses and to the survivors. Such faithfulness becomes in turn the lever for a resistance to modes of visuality, in Mirzoeff's acceptation of the term, and a means to reconsider the invisibility of surviving. By whetting the reader's perception and training his/her consideration, the novel favours what Laugier has called "a democratic economy of 
attention", ${ }^{57}$ meaning that all subjects, even the humblest and most violently relegated, are worthy of attention — the latter being an activity for everybody to practise.

I would argue that by re-writing the elegiac script and privileging the melancholic option, by performing the experience of survival and by rescuing survivors from invisibility, Even the Dogs respects its self-imposed ethical and political agenda and contributes its (angry) mite to narrative democracy. By focussing on the figures of the downtrodden and the excluded (those who are kept outside, even if such an outside lies within the pale), it trains our consideration, in Pelluchon's sense of the term, i.e. our capacity to remain on a level with the survivors instead of looming over them, adopting a humble attitude to connect with their humility (meant as their closeness to the ground). ${ }^{58}$ This is made possible by privileging a type of experimental narrative that favours the experiential over the merely rational, in so far as the novel never allows the reader to veer away from vibrant reminders of incarnation, suggesting that dependence, responsibility and the capacity for survival begin in the body.

From this point of view, Even the Dogs may be situated within a context of production that gives prominence to what has been called "new materialism", a new mode of being that underlines "the material dimension of social life", 59 hence the subject's inherently relational dimension. Among the objects whose vibrant materiality it chooses to put forward are the weeds and flowers that keep growing in the urban wasteland that the narrative takes as its background. This is what McGregor has indicated in an interview:

[...] that's why I was so pleased with the image they chose for the British cover of the book, because on a metaphorical level and on an actual literal level, I was quite interested in the imagery of the flowers which survive against the odds. [... H] opefully it comes through naturally that that's what these people are doing-surviving constantly in a very creative and inventive way. ${ }^{60}$

Through the image of the striving, surviving weeds and flowers, a strong sense of creativity is built into the novel, whose ethics is also a politics of healing or redressing, and which 
proclaims the clinical, caring purpose of literature. Some might analyse this in terms of resilience, but I would rather refer to a term hailing from the altogether different context of art theory: survivance. In one of his very influential essays, Survival of the Fireflies (La survivance des lucioles), French art historian Georges Didi-Huberman takes the image of the "minor light" (emphasis in the original) cast by the fireflies to insist on the humble ways in which resistance and indestructibility manifest themselves in the face of adversity. I would say that, like the fireflies that are exposed to disappearance in the contemporary context of multi-dimensional pollution, the survivors in Even the Dogs are shown in their dispossession and vulnerability the better to be apprehended through their resistance. It is ultimately such a positive image of survivance that emerges from McGregor's engagement with survival and its ghostly and incarnated figures.

\section{Endnotes}

${ }^{1}$ Agamben (2002, 33).

${ }^{2}$ Agamben $(2002,15)$.

${ }^{3}$ Agamben (2002, 34).

${ }^{4}$ Lyotard (2008, 9).

${ }^{5}$ Felman and Laub $(1992,6)$.

${ }^{6}$ Felman and Laub (1992, 80; emphasis in the original).

${ }^{7}$ Caruth $(1996,60)$.

${ }^{8}$ Caruth (1996, 61; emphasis in the original).

${ }^{9}$ Caruth (1996, 64; emphasis in the original).

${ }^{10}$ Didi-Huberman (2008, 26-27).

${ }^{11}$ Didi-Huberman $(2008,33)$.

${ }^{12}$ See Kennedy $(2007,2)$.

${ }^{13}$ In an interview, McGregor has confirmed, if need be, that he feels "the novel is very much concerned with mourning" and that the mourners are the key image of the novel; see McGregor (2010b, 241).

${ }^{14}$ See McGregor (2010a, 189); McGregor (2010b, 242). 
${ }^{15}$ McGregor (2010a, 11).

${ }^{16}$ Felman and Laub $(1992,85)$. I am aware of the fact that Laub's words are applied to nonfictional accounts, and that I am applying them to the field of fiction or what I have called above "fictional testimony". Still, I am also conscious of the fact that all narratives, whether directly referential or fictional, are based on emplotment and figurative language, which produces a form of continuum between an ideal pole of total non-fictional transparency and another one associated with fictional opaqueness. My position is that the figurative and the fictional cannot be barred access from the responsibility of bearing witness. One of the ways of doing this ethically is by refusing to use older, all-purpose forms that fail to respect the singularity of the presented situation. This is where experimental fiction comes in, when it is devised, as is the case with Even the Dogs - and as was the case with Time's Arrow, for instance-, to provide an innovative, adapted formal solution to respect the singularity of the situation that it addresses.

${ }^{17}$ Felman and Laub $(1992,89)$.

${ }^{18}$ Kennedy (2007, 20 and 28).

${ }^{19}$ McGregor (2010a, 195).

${ }^{20}$ McGregor (2010a, 214).

${ }^{21}$ Ramazani (1994, 37).

${ }^{22}$ Levine $(2006,1)$.

${ }^{23}$ Clifton (2004, 24).

${ }^{24}$ McGregor (2010a, 102).

${ }^{25}$ Felman and Laub $(1992,84)$.

${ }^{26}$ Levine (2006, 4).

${ }^{27}$ Butler (2005, 32; emphasis in the original).

${ }^{28}$ Arnds $(2012,163)$.

${ }^{29}$ Latour $(1993,47)$.

${ }^{30}$ MacIntyre $(2002,1)$.

${ }^{31}$ Agamben $(2002,17)$.

${ }^{32}$ On McGregor's use of an opaque poetic prose, see for instance Alexander (2013, 748-749).

${ }^{33}$ McGregor (2010a, 122).

${ }^{34}$ McGregor (2010a, 142-143).

${ }^{35}$ Revault d'Allonnes (2016, np; my translation)

${ }^{36}$ Laugier $(2014,264)$. 
${ }^{37}$ Pelluchon (2018, 61; my translation).

${ }^{38}$ Pelluchon (2018, 89; my translation).

${ }^{39}$ Bernard (2018, 68; my translation).

${ }^{40}$ Korte and Zipp (2014, 69-73).

${ }^{41}$ Ganteau $(2015,135-48)$.

${ }^{42}$ Le Blanc (2011, 41; my translation).

${ }^{43}$ Le Blanc (2011, 18; my translation).

${ }^{44}$ McGregor (2010a, 91).

${ }^{45}$ Le Blanc (2010, 176; my translation).

${ }^{46}$ McGregor (2010a, 134).

${ }^{47}$ Le Blanc (2009, 76; my translation).

${ }^{48}$ Le Blanc $(2009,13)$.

${ }^{49}$ Le Blanc (2009, 13; my translation).

${ }^{50}$ Le Blanc (2009, 91; my translation).

${ }^{51}$ Mirzoeff (2011, xv).

${ }^{52}$ McGregor (2010a, 158).

${ }^{53}$ Mirzoeff $(2011,24)$.

${ }^{54}$ Mirzoeff $(2011,4)$.

${ }^{55}$ Laugier $(2014,252)$.

${ }^{56}$ Le Blanc (2010, 176; my translation).

${ }^{57}$ Laugier (2014, 265).

${ }^{58}$ Pelluchon (2018, 31-33).

${ }^{59}$ Coole and Fox $(2010,16)$.

${ }^{60}$ McGregor (2010b, 221).

\section{Works Cited}

Agamben, Giorgio. 2002 [1999]. Remnants of Auschwitz: The Witness and the Archive. New York: Zone Books. 
Alexander, Neal. 2013. "Profoundly Ordinary: Jon McGregor and Everyday Life." Contemporary Literature 54 (4): 720-751.

Améry, Jean. 1988 [1966]. At the Mind's Limits: Contemplation by a Survivor of Auschwitz and Its Realities. Bloomington and Indianapolis: Indiana University Press.

Amis, Martin. 1992 [1991]. Time's Arrow, or The Nature of the Offence. Harmondsworth: Penguin.

Antelme, Robert. 1998. The Human Race. 1947. Chicago: Northwestern University Press.

Arnds, Peter. 2012. “Translating Survival, Translation as survival in Primo Levi’s Se questo è un uomo." Translation and Literature 21 (2): 162-174.

Berger, John. 2000 [1999]. King: A Street Story. London: Vintage.

Bernard, Catherine. 2018. Matière à réflexion: Du corps politique dans la littérature et les arts britanniques contemporains. Paris: PUPS.

Butler, Judith. 2005. Giving an Account of Oneself. New York: Fordham University Press.

Caruth, Cathy. 1996. Unclaimed Experience. Trauma, Narrative and History. Baltimore: Johns Hopkins University Press.

Clifton, R. Spargo. 2004. The Ethics of Mourning: Grief and Responsibility in Elegiac Literature. Baltimore: Johns Hopkins University Press.

Coleridge, Samuel Taylor. 2000. “Limbo.” Selected Poems, 214. London: Penguin Classics.

Coole, Diana, and Samantha Fox. 2010. "Introducing the New Materialism.” In New Materialisms: Ontology, Agency and Politics, edited by Diana Coole and Samantha Fox, 1-35. Durham: Duke University Press.

Didi-Huberman, Georges. 2008 [2003]. Images in Spite of All: Four Photographs from Auschwitz. Chicago: University of Chicago Press.

Didi-Huberman, Georges. 2018a [2008]. Survival of the Fireflies. Minneapolis: University of Minnesota Press. 
Didi-Huberman, Georges. 2018b [2002]. The Surviving Image: Phantoms of Time and Times of Phantoms: Aby Warburg's History of Art. University Park: Pennsylvania State University Press.

Felman, Shoshana, and Dori Laub. 1992. Testimony: Crises of Witnessing in Literature, Psychoanalysis and History. London: Routledge.

Ganteau, Jean-Michel. 2015. The Ethics and Aesthetics of Vulnerability in Contemporary British Fiction. London: Routledge.

Kennedy, David. 2007. Elegy. London: Routledge.

Korte, Barbara, and Georg Zipp. 2014. Poverty in Contemporary Literature: Themes and Figurations on the British Book Market. Houndmills, Basingstoke: Macmillan.

Latour, Bruno. 1993 [1991]. We Have Never Been Modern. London: Harvester Wheatsheaf.

Laugier, Sandra. 2014. "L'éthique comme attention à ce qui compte." In L'économie de l'attention, edited by Yves Citton, 252-66. Paris: La Découverte.

Le Blanc, Guillaume. 2009. L'invisibilité sociale. Paris: Presses Universitaires de France.

Le Blanc, Guillaume. 2010. Dedans, dehors: La condition d'étranger. Paris: Seuil.

Le Blanc, Guillaume. 2011. Que faire de notre vulnérabilité. Paris: Bayard.

Levi, Primo. 1969 [1947]. If This Is a Man. Harmondsworth: Penguin.

Levine, Michael G. 2006. The Belated Witness: Literature, Testimony, and the Question of Holocaust Survival. Stanford: Stanford University Press.

Lyotard, Jean-François. 2008 [1983]. The Differend: Phrases in Dispute. Manchester: Manchester University Press.

McGregor, Jon. 2010a. Even the Dogs. London: Bloomsbury.

McGregor, Jon. 2010b. “An Interview with Jon McGregor.” Conducted by Caroline Edwards. Contemporary Literature 51 (2): 217-245. 
McIntyre, Alasdair. 2002 [1999]. Dependent, Rational Animals: Why Human Beings Need the Virtues. Peru: Carus Publishing.

Mirzoeff, Nicholas. 2011. The Right to Look: A Counterhistory of Visuality. Durham: Duke University Press.

Pelluchon, Corine. 2018. Éthique de la considération. Paris: Seuil.

Ramazani, Jahan. 1994. Poetry of Mourning: The Modern Elegy from Hardy to Heaney. Chicago: University of Chicago Press.

Revault d'Allonnes, Myriam. 2016. Le miroir et la scène: Ce que peut la représentation politique. Paris: Seuil. Ebook.

Schwab, Gabrielle. 2010. Haunting Legacies: Violent Legacies and Transgenerational Trauma. New York: Columbia University Press. 